\title{
Characterization and Use of Egyptian Nubian Sandstone in the Ceramic Tile Industry
}

\author{
S. A. El-Sherbiny ${ }^{1}$ and Sh. K. Amin ${ }^{2 *}$
}

${ }^{1}$ Chemical Engineering Department, Faculty of Engineering, Cairo University, Giza, Egypt

${ }^{2}$ Chemical Engineering \& Pilot Plant Department, Engineering Division, National Research Center, Dokki, Giza, Egypt

\begin{abstract}
Egyptian ball clay quarried in the Aswan area in Upper Egypt contains up to 10\% Nubian sandstone. This inclusion causes problems in clay grinding when used in ceramic industries. In the present paper, Nubian sandstone was characterized for mineralogical and chemical compositions using XRD and XRF respectively. Its grinding characteristics were then established using a laboratory ball mill where stone was ground for time periods ranging from 60 to $150 \mathrm{~min}$ at speeds ranging from 40 to $90 \mathrm{rpm}$. The cumulative analysis and specific surface area were determined for all samples. It was found that while an increase in either time or speed favoured higher fineness, the effect of rotating speed was more pronounced than that of grinding time. The findings were then applied to the production of ceramic tiles. It was found that crushed sandstone could be crushed and ground with ball clay without impairing the grinding characteristics of the latter or affecting the composition of the final body.
\end{abstract}

Keywords: Nubian sandstone; Grindability; Particle size distribution; Specific surface area

\section{Introduction}

Clay raw materials are particularly used in the ceramic industry. They have however been of importance in many other fields of application that include agriculture, civil works, process industries, etc.

Nubian sandstone is one of the impurities found with the clay ore. It commonly consists of brown or reddish stones referring to a variety of sedimentary rocks deposited on the Precambrian basement in the Eastern Sahara, North-East Africa and Arabia. The hardness of Nubian sandstone depends on its origin. In certain places it is extremely friable, and in others compact and hard [1]. Some local samples obtained from Sinai in Egypt contain $65 \% \mathrm{SiO}_{2}$ and $20 \% \mathrm{Al}_{2} \mathrm{O}_{3}$, a composition close to that of potash feldspar, which indicates that the use of the associated sandstone along with the clay may not affect the properties of products using clay and feldspar as raw materials [2]. In Upper Egypt, beds of clays and Nubian sandstone alternate, the level of sandstone in these clays ranging from $5-10 \%[3]$.

In order to confirm the feasibility of using the Nubian sandstone, grindability studies were performed through crushing and grinding experiments. These tests showed that the grindability of the mineral ores depends more on their composition and properties (fracture toughness, homogeneity of the structure) than on their hardness $[4,5]$.

\section{Grinding is an energy-intensive operation}

$5 \%$ of the total energy consumption of developed countries is directed to crushing and grinding processes [6,7]. Since some of the energy used will be converted into heat that will not be utilized in the grinding process, thus, the grinding parameters should be well studied so as to optimize the use of input energy $[2,8]$. In particular, proper grinding of clay minerals is essential in influencing positively their behaviour in subsequent processing steps $[9,10]$.

The objective of this paper is to investigate the grinding behaviour of Aswan Nubian sandstone and the possibility of its simultaneous grinding with clay as raw material in the ceramic tile industry, without affecting neither the subsequent processing steps. The grinding behaviour of Nubian sandstones was assessed by obtaining the particle size distribution of the ground product and calculating its specific surface area or alternatively the mean surface-volume diameter of the ground product [11].

\section{Experimental}

\section{Assessment of raw materials}

The raw materials used mainly consist of two portions: The first part is Aswan clay (Upper Egypt), while the second part includes Aswan Nubian sandstone samples were obtained from PRIMA Factory, Sadat City, Egypt.

The as-received samples of clay and sandstone were hand-crushed to reduce their size in order to obtain smaller particle size that can be easily ground in a laboratory ball mill.

(Table 1) shows the screen analysis of the hand-crushed samples used before performing grinding procedures $[12,13]$.

Both clay and sandstone were analyzed by X-ray Fluorescence (XRF) using an AXIOS, panalytical 2005, Wavelength Dispersive (WD-XRF) Sequential Spectrometer, and by X-ray diffraction (BRUKUR D8 ADVANCE COMPUTERIZED X-Ray Diffractometer), using a mono-chromatized $\mathrm{Cu}$ Ka radiation.

Free silica, combined with clay minerals was also determined using the classical method of Trostel et al. [14]. Also, the percent organic matter was determined by using a hydrogen peroxide solution $(30 \%)$ to free clay from its organic matters [15].

*Corresponding author: Dr. Shereen Kamel Amin, Chemical Engineering and Pilot Plant Department, Engineering Division, National Research Center, Dokki, Giza, Egypt, Tel: 202-33335494; Fax: 202-33370931; E-mail: sheren51078@yahoo.com,dr.shereenkamel@hotmail.com

Received April 25, 2012; Accepted August 18, 2012; Published August 25, 2012

Citation: El-Sherbiny SA, Amin SK (2012) Characterization and Use of Egyptian Nubian Sandstone in the Ceramic Tile Industry. J Material Sci Eng 1:112. doi:10.4172/2169-0022.1000112

Copyright: (c) 2012 El-Sherbiny SA, et al. This is an open-access article distributed under the terms of the Creative Commons Attribution License, which permits unrestricted use, distribution, and reproduction in any medium, provided the original author and source are credited. 
The true density of clay and sandstone were measured using the standard pycnometer method (Density flask) [16].

\section{Equipment}

Grinding tests were performed in a RETSCH centrifugal ball mill $(\mathrm{S} 100)$. The grinding jar $(500 \mathrm{ml})$ rotates in a horizontal plane and was charged with 106 balls ranging from 7.8 to $10 \mathrm{~mm}$ diameter with a total ball load weighing $310.68 \mathrm{~g}$, grinding balls with different particle sizes being used to increase the grinding rate [17].

The centrifugal forces that are generated propel the balls against the inside wall of the jar, where they roll over the sample. Grinding is therefore effected by way of impact and attrition. The improvement of specific surface is associated with reduction of resistance to comminution and prevention of agglomeration and powder coating of balls and mill [18].

Mill characteristic and test conditions for grinding are shown in (Table 2).

For each test, $200 \mathrm{~g}$ of the sample previously described in (Table 1) was separately ground at different times $(60,90,120$, and $150 \mathrm{~min})$. After the grinding of each batch, the mill content was discharged and the sample was sieved for 30 minutes.

The fine sieves were cleaned using air blower and the batch is rescreened for another 30 minutes to prevent clogging (blockage) of the sieves openings and ensure complete screening of the finely ground samples.

The retained weights were recorded for each screen size and the specific surface area for the batch was calculated from the following equation [19]

$$
\mathrm{A}_{\mathrm{w}}=6 \frac{\varphi}{\rho} \Sigma \frac{\mathrm{x}_{\mathrm{i}}}{\mathrm{D}_{\mathrm{avi}}}
$$

Where:

$$
\begin{aligned}
& \text { A : Specific surface area, } \mathrm{m}^{2} \\
& \varphi \text { : Shape factor (Taken as } 1.2 \text { ) } \\
& \rho: \text { Density, } \mathrm{kg} / \mathrm{m}^{3}
\end{aligned}
$$

\begin{tabular}{|c|c|c|}
\hline Mesh size & Size of opening $\mathbf{( m m})$ & Retained weight $\mathbf{( g )}$ \\
\hline 4 & 4.75 & 79.7 \\
\hline 10 & 2 & 64.7 \\
\hline 18 & 1 & 25 \\
\hline 25 & 0.71 & 6.6 \\
\hline 50 & 0.3 & 10.8 \\
\hline 100 & 0.15 & 6.1 \\
\hline 200 & 0.075 & 3.4 \\
\hline 270 & 0.053 & 3.7 \\
\hline Pan & 0 & 0 \\
\hline
\end{tabular}

Table 1: Screen analysis of crushed samples before grinding.

\begin{tabular}{|c|c|c|}
\hline \multirow{2}{*}{ Mill Bowl } & Bowl material & Stainless Steel \\
\cline { 2 - 3 } & Bowl volume & $500 \mathrm{cc}$ \\
\cline { 2 - 3 } & Speed & $\begin{array}{c}\text { Variable } \\
(10-100 \mathrm{rpm})\end{array}$ \\
\hline \multirow{2}{*}{ Mill Charge } & Balls diameter & $7.8-10 \mathrm{~mm}$ \\
\hline Clay and Sandstone Samples & Total balls weight & $310.68 \mathrm{~g}$ \\
\hline
\end{tabular}

Table 2: Mill characteristics and test conditions.

\begin{tabular}{|c|c|c|}
\hline Constituents (wt. \%) & Aswan Clay & Nubian Sandstone \\
\hline $\mathrm{SiO}_{2}$ & 47.7 & 65.01 \\
\hline $\mathrm{TiO}$ & 1.57 & 1.9 \\
\hline $\mathrm{Al} 2 \mathrm{O} 3$ & 23.89 & 19.6 \\
\hline $\mathrm{Fe} 2 \mathrm{O} 3$ & 13.57 & 3.85 \\
\hline $\mathrm{MnO}$ & & 0.01 \\
\hline $\mathrm{MgO}$ & 0.23 & 0.35 \\
\hline $\mathrm{CaO}$ & 0.61 & 0.16 \\
\hline $\mathrm{Na2O}$ & 0.12 & 0.2 \\
\hline $\mathrm{K} 2 \mathrm{O}$ & 0.92 & 0.61 \\
\hline $\mathrm{P} 2 \mathrm{O} 5$ & 0.17 & 0.04 \\
\hline $\mathrm{SO} 3$ & 0.42 & 0.03 \\
\hline $\mathrm{Cl}$ & 0.04 & 0.18 \\
\hline L.O.I & 10.37 & 8.02 \\
\hline Total & 99.61 & 99.96 \\
\hline
\end{tabular}

Table 3: Chemical composition of raw materials.

$\mathrm{X}_{\mathrm{i}}$ : mass fraction of retained weight on each screen

$\mathrm{D}_{\text {avi }}$ : average particle size of each mass fraction, $\mathrm{m}$

\section{Application in ceramic tiles industry}

A sample where $10 \%$ Aswan clay (by weight) was replaced by Nubian sandstone was shaped in a tile form of $100 \times 100 \mathrm{~mm}^{2}$ and 8.5 $\mathrm{mm}$ thickness. Six glazed tiles were prepared. Three of them were floor tiles, while the other three were wall tiles.

These tile specimens were dry pressed (30 MPa), glazed then fired in a production line of a factory through a single fast firing technique, in a roller kiln. The maximum firing temperature was $1175^{\circ} \mathrm{C}$ for floor tiles and $1145^{\circ} \mathrm{C}$ for wall tiles. The total firing time was 40 minutes in both cases.

The tile samples were then tested in conformity with the internationally harmonized Egyptian standards of ceramic tiles [20,21].

\section{Results and Discussion}

\section{Characterization of the raw materials}

Chemical composition: Table 3 shows the chemical analysis of Aswan clay and Nubian sandstone as a result of XRF. From this Table, it can be observed that, the Nubian sandstone is rich in silica, which constitutes about $65 \%$ of its weight. It also contains reasonable amount of $\mathrm{Al}_{2} \mathrm{O}_{3}$ that helps in aluminium silicates formation. It is also rich in iron oxide that acts as fluxing material.

\section{XRD Investigation}

Figures (1 and 2) show the XRD pattern of Aswan clay and Nubian sandstone, respectively. XRD analysis showed that the phases present in clay are: Kaolinite $\left[\mathrm{Al}_{2} \mathrm{Si}_{2} \mathrm{O}_{5}(\mathrm{OH})_{4}\right]$, Quartz $\left[\mathrm{SiO}_{2}\right]$, and Illite. While the phases present in Nubian sandstone are: Quartz $\left[\mathrm{SiO}_{2}\right]$, Kaolinite $\left[\mathrm{Al}_{2} \mathrm{Si}_{2} \mathrm{O}_{5}(\mathrm{OH})_{4}\right]$, and Anatase $\left[\mathrm{TiO}_{2}\right]$.

Free silica, organic matter, and true density: Free silica, associated with clay mineral, was determined to be $2.5 \%$. The combined silica is liberated as silicic acid and is subsequently dissolved in a hot sodium hydroxide solution.

Also, the organic matter was determined by using the hydrogen peroxide method. The percent of organic matter $=2 \%$.

The true densities of clay and sandstone were 2.41 and $2.08 \mathrm{~g} / \mathrm{cm}^{3}$, respectively. 


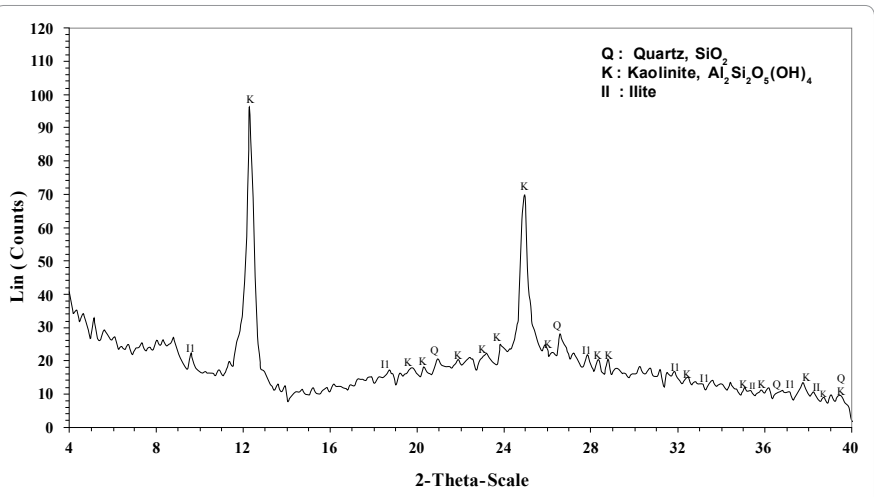

Figure 1: XRD pattern of clay.

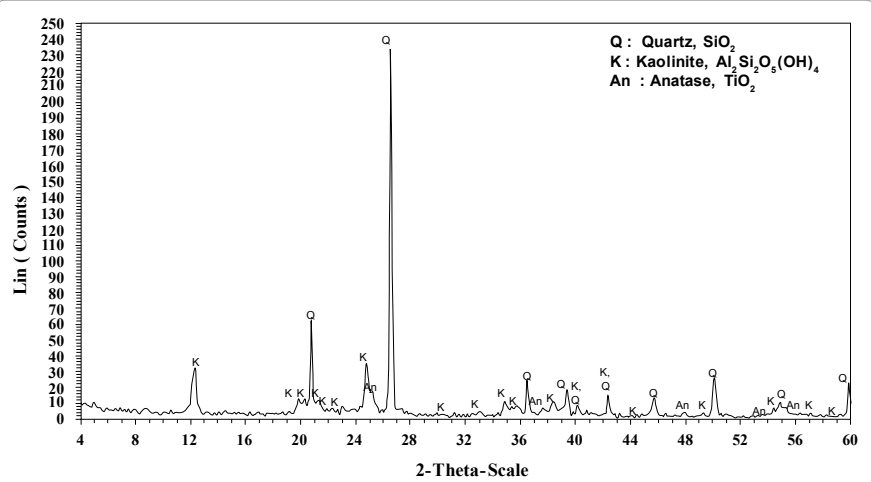

Figure 2: XRD pattern of Nubian sandstone.

\section{Influence of Particle Size Distributions}

From Figures ( 3 to 5 ) show the cumulative screen analysis results of pure Nubian sandstone ground at different milling times and speeds $=40,60$, and $90 \mathrm{rpm}$, respectively. Other speeds were also tried but it was found unnecessary to include them.

From these figures, it was found that while an increase in either time or speed favoured higher fineness, the effect of rotating speed is more pronounced than that of grinding time. It was possible to verify this premise by constructing a correlation table using the DATA ANALYSIS module. This is shown in (Table 4) from which it can be deduced that the effect of mill speed highly exceeds that of grinding time.

It was also possible to linearly correlate the specific area of the ground product to the two aforementioned variables using the same module. The following relation was obtained with a multiple correlation coefficient $\mathrm{R}=0.965$ :

Table 5 shows the specific surface area calculated for pure Nubian sandstone at different milling times and speeds $=40,50,60,70,80$, and $90 \mathrm{rpm}$, respectively while (Figure 6) shows the effect of milling time on the specific surface area for different milling speeds. This figure shows that the specific surface area increases with time and mill speed to reach almost constant values except at high rpm where more time is needed for the specific surface area values to stabilize.

Figure 7 shows a comparison between experimental and calculated data for specific surface area from equation (1). It is clear that the data is fairly distributed around the $45^{\circ}$ line.

\section{Application in Ceramic Tiles Industry}

Figure 8 shows the cumulative screen analysis results of pure Aswan clay grinding at different milling times and rotating speed $=60 \mathrm{rpm}$, while (Figure 9) shows the effect of adding Nubian sandstone to Aswan clay at different percentage on the cumulative screen analysis results of mixtures at milling speed $=60 \mathrm{rpm}$, and time $=60 \mathrm{~min}$. A comparison of these two figures shows that the screen analysis of clay - sandstone

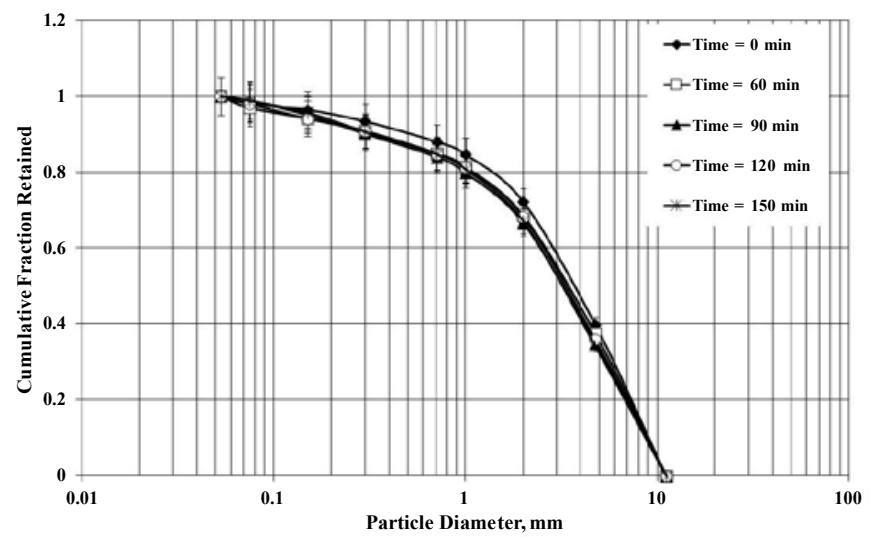

Figure 3: Cumulative fraction of pure Nubian sandstone retained at different times and $\mathrm{rpm}=40$.

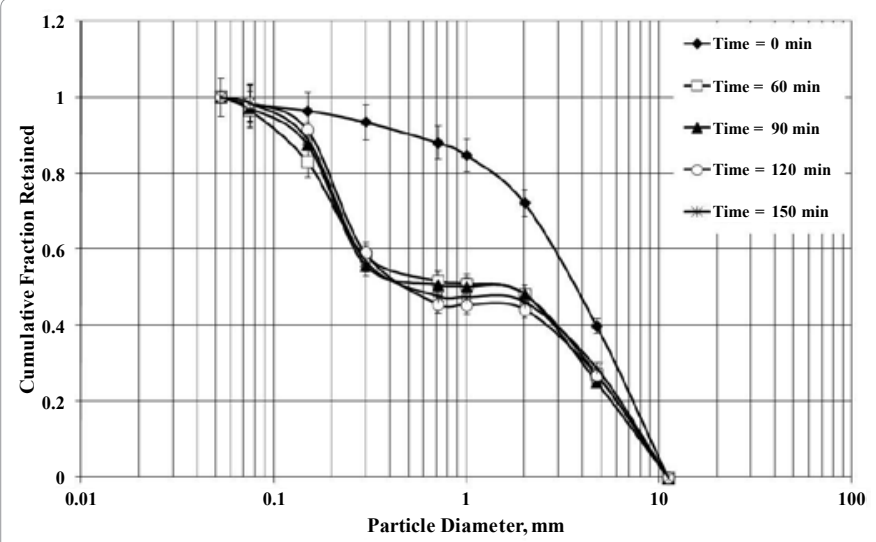

Figure 4: Cumulative fraction of pure Nubian sandstone retained at different times and $\mathrm{rpm}=60$.

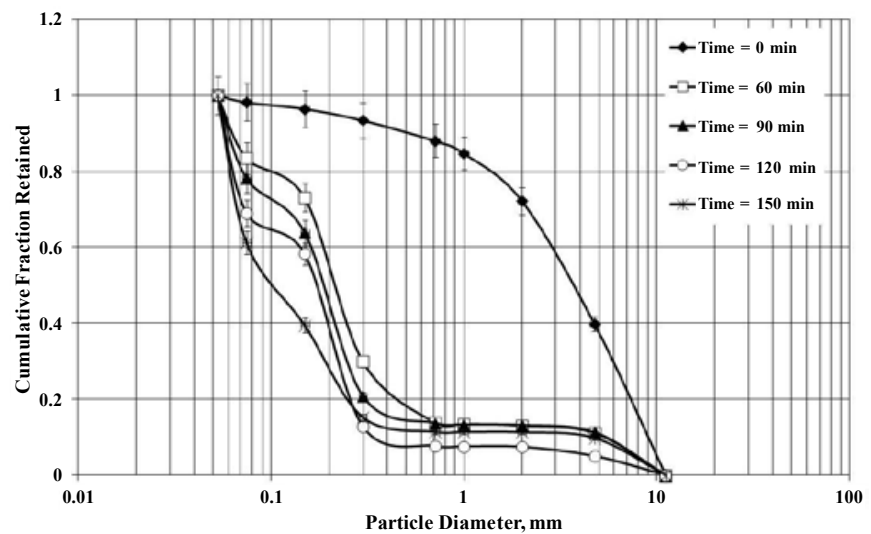

Figure 5: Cumulative fraction of pure Nubian sandstone retained at different times and $\mathrm{rpm}=90$. 


\begin{tabular}{|c|c|c|c|}
\hline & Time & rpm & Specific Area \\
\hline Time & 1 & & \\
\hline rpm & 0 & 1 & \\
\hline Specific Area & 0.162 & 0.951 & 1 \\
\hline
\end{tabular}

Table 4: Relative effect of variables on specific area

\begin{tabular}{|c|c|c|c|c|c|c|}
\hline Time, min & $\mathbf{0}$ & $\mathbf{6 0}$ & $\mathbf{9 0}$ & $\mathbf{1 2 0}$ & $\mathbf{1 5 0}$ \\
\hline $\mathbf{r p m}$ & \multicolumn{5}{|c|}{ Specific Surface Area, $\mathbf{~ m}^{\mathbf{2}} \mathbf{k g}$} \\
\hline $\mathbf{4 0}$ & 3.408 & 4.491 & 4.058 & 4.290 & 3.861 \\
\hline $\mathbf{5 0}$ & 3.408 & 4.801 & 6.050 & 5.158 & 6.111 \\
\hline $\mathbf{6 0}$ & 3.408 & 11.072 & 10.480 & 9.549 & 10.009 \\
\hline $\mathbf{7 0}$ & 3.408 & 16.394 & 16.036 & 19.030 & 20.960 \\
\hline $\mathbf{8 0}$ & 3.408 & 17.552 & 22.356 & 22.133 & 24.344 \\
\hline $\mathbf{9 0}$ & 3.408 & 20.697 & 24.241 & 28.436 & 32.859 \\
\hline
\end{tabular}

Table 5: Specific surface area for Nubian sandstone for different milling time.

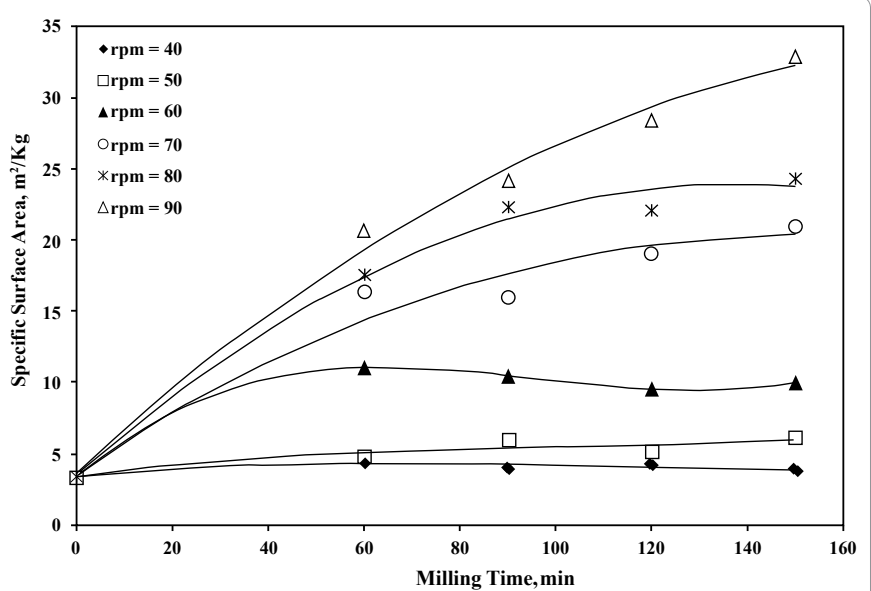

Figure 6: Effect of milling time on the specific surface area for different milling speeds.

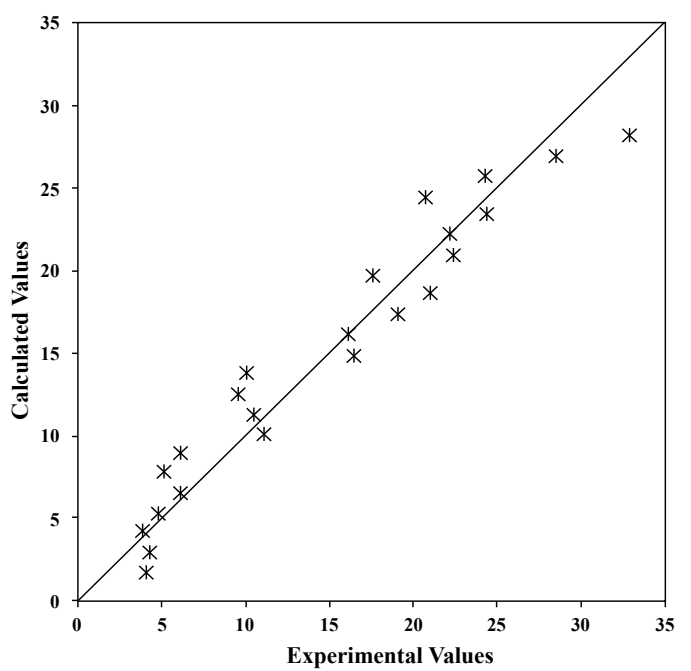

Figure 7: Comparison between experimental and calculated data for specific surface area.

mixtures is very close to that of pure kaolin. Since the level of sandstone in Aswan clays usually ranges from 10 to $20 \%$ [3], it is best to compare the surface area curves of pure clay to that of a mixture containing 5 and $10 \%$ sandstone. Table 6 shows the comparison of particle size at three

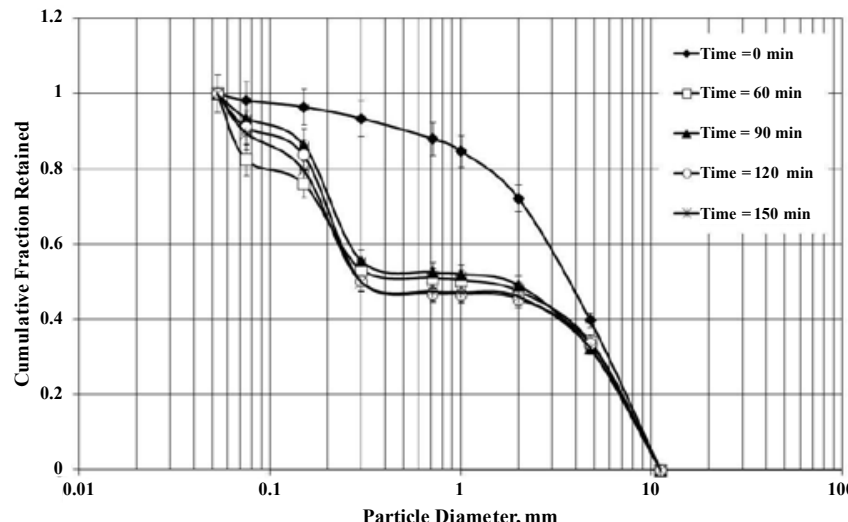

Figure 8: Cumulative fraction of pure Aswan clay retained at different times and $\mathrm{rpm}=60$.

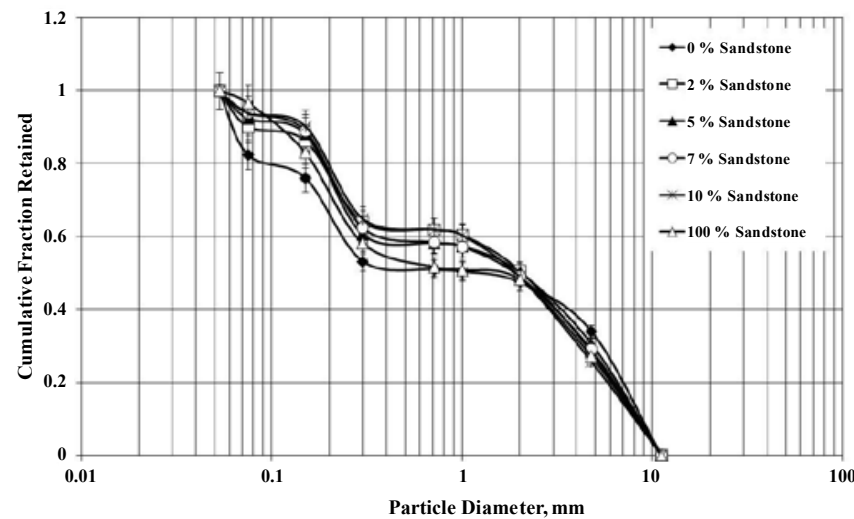

Figure 9: Cumulative fraction of Aswan clay - Nubian sandstone mixtures retained at time $=60 \mathrm{~min}$, and $\mathrm{rpm}=60$.

\begin{tabular}{|c|c|c|c|}
\hline \% retained & $\mathbf{0} \%$ s.s. & $\mathbf{5 \%}$ s.s. & $\mathbf{1 0} \%$ s.s. \\
\hline $\mathbf{2 5} \%$ & $7 \mathrm{~mm}$ & $7 \mathrm{~mm}$ & $6 \mathrm{~mm}$ \\
\hline $\mathbf{5 0} \%$ & $1.6 \mathrm{~mm}$ & $1.7 \mathrm{~mm}$ & $1.9 \mathrm{~mm}$ \\
\hline $\mathbf{7 5} \%$ & $0.17 \mathrm{~mm}$ & $0.2 \mathrm{~mm}$ & $0.2 \mathrm{~mm}$ \\
\hline
\end{tabular}

Table 6: Comparison between particle size of pure ground clay and clay + sandstone (5 and $10 \%$ ).

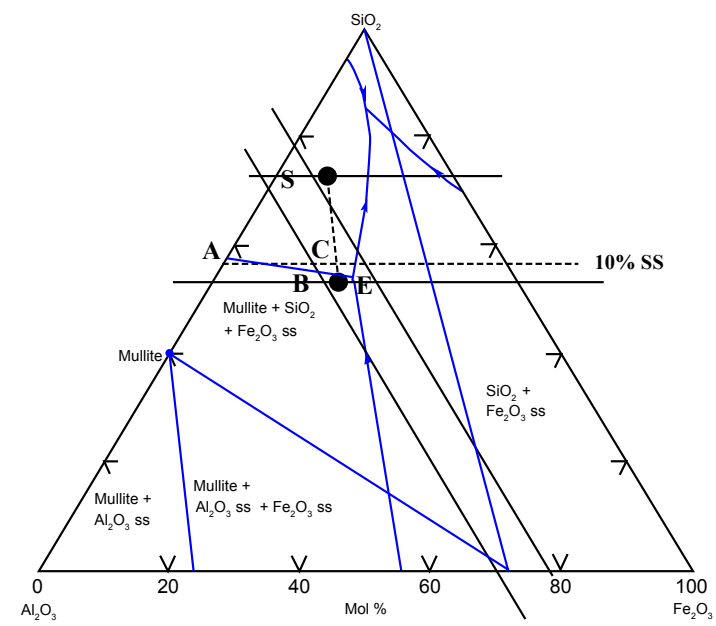

Figure 10: Equilibrium phase diagram of the system $\mathrm{Al}_{2} \mathrm{O}_{3}-\mathrm{Fe}_{2} \mathrm{O}_{3}-\mathrm{SiO}_{2}$. 


\begin{tabular}{|c|c|c|c|c|c|c|c|c|c|c|}
\hline Properties & Tiles Type & $\begin{array}{l}\text { Water } \\
\text { Absorption (\%) }\end{array}$ & $\begin{array}{l}\text { Breaking } \\
\text { Strength } \\
(\mathrm{N})^{*}\end{array}$ & $\begin{array}{l}\text { Modulus of } \\
\text { Rupture (N/ } \\
\mathrm{mm} 2)^{*}\end{array}$ & $\begin{array}{l}\text { Abrasion } \\
\text { Resistance } \\
\star *\end{array}$ & $\begin{array}{l}\text { Crazing } \\
\text { Resistance }\end{array}$ & $\begin{array}{l}\text { Coefficient of } \\
\text { Friction }\end{array}$ & $\begin{array}{l}\text { Resistance } \\
\text { to Staining }\end{array}$ & $\begin{array}{l}\text { Resistance to } \\
\text { Chemicals }\end{array}$ & \\
\hline The Mixture & & & & & & & & & $\begin{array}{l}\text { Low } \\
\text { Concentrations of } \\
\text { Acids and Alkalis }\end{array}$ & $\begin{array}{l}\text { Household } \\
\text { Chemicals } \\
\text { and } \\
\text { Swimming } \\
\text { Pool Salts }\end{array}$ \\
\hline \multirow{2}{*}{$\begin{array}{l}\text { Basic Mixture } \\
\text { ( } 0 \% \text { Replacement ) }\end{array}$} & Floor Tiles & 5.2 & 1541 & 32 & $\begin{array}{l}750-1500 \\
\text { Class (3) }\end{array}$ & pass & 0.3 & Grade (5) & GLA (V) & GA (V) \\
\hline & Wall Tiles & 12.5 & 915 & 19 & & Pass & & Grade (5) & GLA (V) & GA (V) \\
\hline \multirow[t]{2}{*}{$10 \%$ Replacement } & Floor Tiles & 5.9 & 1349 & 29 & $\begin{array}{l}750-1500 \\
\text { Class (3) }\end{array}$ & Pass & 0.3 & Grade (5) & GLA (V) & GA (V) \\
\hline & Wall Tiles & 13.2 & 723 & 15 & & Pass & & Grade (5) & GLA (V) & $\mathrm{GA}(\mathrm{V})$ \\
\hline \multirow[t]{2}{*}{ ES Limits } & Floor Tiles & $3 \%>E \geq 6 \%$ & $\begin{array}{l}\text { Minimum } \\
1000\end{array}$ & $\begin{array}{l}\text { Minimum } \\
22\end{array}$ & $\begin{array}{l}\text { Manufacturer } \\
\text { reports } \\
\text { abrasion } \\
\text { class and } \\
\text { cycles }\end{array}$ & $\begin{array}{l}\text { No Crazing } \\
\text { in glazed } \\
\text { layer }\end{array}$ & $\begin{array}{l}\text { Manufacturer } \\
\text { states the } \\
\text { class }\end{array}$ & $\begin{array}{l}\text { Minimum } \\
\text { Grade (3) }\end{array}$ & $\begin{array}{l}\text { Manufacturer } \\
\text { states } \\
\text { classification }\end{array}$ & $\begin{array}{l}\text { Minimum } \\
\text { GB (V) }\end{array}$ \\
\hline & Wall Tiles & $E>10 \%$ & $\begin{array}{l}\text { Minimum } \\
600\end{array}$ & $\begin{array}{l}\text { Minimum } \\
12\end{array}$ & & $\begin{array}{l}\text { No Crazing } \\
\text { in glazed } \\
\text { layer }\end{array}$ & & $\begin{array}{l}\text { Minimum } \\
\text { Grade (3) }\end{array}$ & $\begin{array}{l}\text { Manufacturer } \\
\text { states } \\
\text { classification }\end{array}$ & $\begin{array}{l}\text { Minimum } \\
\text { GB (V) }\end{array}$ \\
\hline
\end{tabular}

* For thickness $\geq 7.5 \mathrm{~mm}$.

** For tiles intended for use on floors

Where:

- GLA = Glazed, Low concentrations, Non significant change.

- GA = Glazed, Non significant change.

- GB = Glazed, Apparent change in appearance.

$-\mathrm{V}=$ Visual Evaluation.

Table 7: Quality assessment of $10 \%$ wt. Nubian sandstone substituted glazed tiles.

percentiles. It clearly shows that these sizes are fairly close to each other. So, it can be concluded that Nubian sandstone can be simultaneously crushed and ground with Aswan clay without impairing the grinding characteristics of the latter.

On the other hand six prepared fired tile specimens in which $10 \%$ of Aswan clay was substituted by sandstone were tested for the following properties: percent water absorption, breaking strength, MOR, abrasion resistance, crazing resistance, coefficient of friction, resistance to staining and chemicals according to harmonized Egyptian standards $[20,21]$. The results (Table 7) show that such specimens complies the standards allowable limits for both floor and wall tiles. Despite this compliance, it is clear that the water absorption and consequently the porosity of samples have increased by adding sandstone waste as compared to waste free samples. Also, the values of MOR have slightly decreased thereof. The interpretation of the changes in physicomechanical properties on sandstone addition can be understood in light of the diagram $\mathrm{SiO}_{2}-\mathrm{Al}_{2} \mathrm{O}_{3}-\mathrm{Fe}_{2} \mathrm{O}_{3}$ that accounts for most of the components of both sandstone and clay. Figure 10 shows this phase diagram [22].

The approximate composition of basic mixture is shown on this diagram by point (B) where as point (S) represents that of sandstone. Adding $10 \%$ sandstone to the basic mixture shifts the composition to point (C). The figure shows that point (B) almost lies on the boundary curve (AE) meaning that its initial melting point is lower than that of point $(\mathrm{C})$. This means that adding $10 \%$ sandstone to the basic mixture will have for effect to decrease the amount of liquid phase formed on firing. This in turns is responsible for the increase in water absorption and the decrease in mechanical strength outlined in Table 7.

A decrease in staining resistance can also be expected because of the decrease in glassy phase content. On firing, the first region to vitrify is the surface of the material. A lower glassy phase would mean higher porosity (as evidenced by higher water absorption) which would result in reduced staining resistance.

\section{Conclusion}

Nubian sandstone is a common impurity that is usually found with the Aswan clay. The XRD and XRF analysis showed that using it along with clay in ceramic tiles will not affect the chemical composition of the final product.

The milling characteristics of Nubian sandstone are an important parameter that could affect its usage with the clay as raw material. The grinding experiments for both Nubian sandstone and Aswan clay showed that a mix of both could be crushed and ground without impairing the grinding characteristics of the latter or affecting the composition of the final ceramic tiles body.

Nubian sandstone can be used as additives to Aswan clay up to $10 \%$ without affecting the grinding characteristics of raw materials used in ceramic tiles industry.

\section{Acknowledgment}

The authors would like to offer special thanks and Deepest gratitude to their main supervisor Prof. Dr. M. F. Abadir, at the Chemical Engineering Department Faculty of Engineering, Cairo University, for suggesting the research point, supervising and following up the experimental work, his efforts in solving the practical problems that faced the authors are deeply appreciated, in addition to his continuous encouragement.

\section{References}

1. Abdel Dayem AL (2010) The Nubian sandstone in Egypt. Nubian sandstone Workshop, University of Manchester.

2. Ipek H, Ucbas $Y$, Yekeler M, Hosten C (2005) Dry grinding kinetics of binary mixtures of ceramic raw materials by Bond milling. Ceramics International 31 1065-1071.

3. Awad AM, El Arabi NE, Hamza MS (1997) Use of solute chemistry and isotopes to identify sources of ground-water recharge in the Nile aquifer system in upper Egypt. Ground Water 35: 223- 228

4. Delagrammatikas G, Delagrammatikas M, Tsimas S (2007) Particle size distributions a new approach. Powder Technology 176: 57-65. 
Citation: El-Sherbiny SA, Amin SK (2012) Characterization and Use of Egyptian Nubian Sandstone in the Ceramic Tile Industry. J Material Sci Eng 1:112. doi:10.4172/2169-0022.1000112

Page 6 of 6

5. Kulu P, Tarbea R, Kaerdi H, Goljandin D (2009) Abrasivity and grindability study of mineral ores. Wear Lausanne 267: 1832-1837.

6. Mucsi G (2008) Fast test method for the determination of the grindability of fine materials. Chemical Engineering Research and Design 86: 395-400.

7. Matijasic G, Zizek K, Sofilic U, Mandic V, Skopal H (2009) Wet comminution kinetics of dolomite at laboratory scale. Chemical Engineering and Processing: Process Intensification 48: 846-851.

8. Bozkurt V, Ozgur I (2007) Dry grinding kinetics of colemanite. Powder Technology 176: 88-92

9. Filipovic-Petrovic LM, Kostic-Gvozdenovic L, Eric-Antonic SC (2002) The effects of fine grinding on the physicochemical properties and thermal behavior of bentonite clay. J Serb Chem Soc 67: 753-760.

10. Balek V, Perez-Maqueda LA, Poyato J, Cerny Z, Ramirez-Valle V, et al. (2007) Effect of grinding on thermal reactivity of ceramic clay minerals. J Therm Anal Calorim 88: 87-91

11. Velazquez ALC, Menendez-Aguado JM, Brown RL (2008) Grindability of lateritic nickel ores in Cuba. Powder Technology 182: 113-115.

12. ASTM (2009) Specifications for wire-cloth sieves for testing purposes. Annual book of American Society for Testing of Material U S A 14.

13. ASTM D 422/1963 (Reapproved 2007) Standard Test Method for Particle-Size Analysis of Soils. Annual book of American Society for Testing of Material (ASTM) USA 4.

14. Trostbl LJ, Wynne DJ (1940) Determination of quartz (free silica) in refractory clays. J Am Ceram Soc 23: 18-22.
15. Mikutta R, Kleber M, Kaiser K, Jahn R (2005) Organic matter removal from soils using hydrogen peroxide, sodium hypochlorite, and disodium peroxodisulfate. Soil Sci Soc Am J 69: 120-135.

16. ES (2006) Testing of physical properties for dense shaped refractory products, Part (2): determination of true density. Egyptian Organization for Standardization and Quality, Cairo, Egypt.

17. Choi WS, Chung HY, Yoon BR, Kim SS (2001) Applications of grinding kinetics analysis to fine grinding characteristics of some inorganic materials using a composite grinding media by planetary ball mill. Powder Technology 115: 209 214

18. Katsioti M, Tsakiridis PE, Giannatos P, Tsibouki Z, Marinos J (2009) Characterization of various cement grinding aids and their impact on grindability and cement performance. Construction and Building Materials 23: 1954-1959.

19. McCabe W, Smith JC, Hariot P, (2005) Unit operations of chemical engineering (7thedn). McGraw Hill

20. ES (2005) Ceramic tiles - Part (4): Dry pressed ceramic tiles with water absorption 3\% > E $\leq 6 \%$ (group Blla). Egyptian Organization for Standardization and Quality Cairo, Egypt.

21. ES (2005) Ceramic tiles - Part (6): Dry pressed ceramic tiles with water absorption $>10 \%$ (group BIII). Egyptian Organization for Standardization and Quality, Cairo, Egypt.

22. Nowotny $\mathrm{H}$, Funk $\mathrm{R}$, (1951) System $\mathrm{Al}_{2} \mathrm{O}_{3}-\mathrm{Fe}_{2} \mathrm{O}_{3}-\mathrm{SiO}_{2}$; equilibrium phases Radex Rundsch 8: 334-340. 